The $5^{\text {th }}$ International Conference on Family Business and Entrepreneurship

\title{
THE IMPACT OF THE PANDEMIC ON THE RADIO BUSINESS IN WEST JAVA-INDONESIA
}

\author{
Ellang Gantoni Malik ${ }^{1}$ \\ ${ }^{1}$ Faculty of management, University of Kebangsaan Republik Indonesia, ellanghadibrata76@ gmail.com
}

\begin{abstract}
The era of disruption and pandemic has changed the economic climate and the calculation of profits for various business sectors, including the service, trade, and manufacturing sectors. in 2020 it is almost certain that there will be a change in the calculation of financial targets both in terms of net present value and internal rate return, as well as in 2021, where profits are under great pressure. The service industry sector is one of the sectors experiencing deep pressure, especially the radio mass media business. Mass media including broadcast radio institutionally has two different sides, firstly commercial and profit-oriented as a business, and secondly social and idealism. The COVID-19 pandemic has been going on for about 17 months and has had a bad impact. as well as the financial impact experienced by radio media, most radio broadcasting media experienced a decrease in income in the range of 50\% - 70\% of normal conditions. Such conditions require radio media to adapt to the situation by rationalization and/or convergence, both in terms of business and social functions to survive. the steps taken are reducing broadcast hours, reducing the number of employees, and other efficiencies. there are even some who stop radio media business activities so that they do not carry out activities at all. The study uses financial analysis, data in the form of annual financial statements of income, in addition to financial statement data, direct interviews with decision-makers are carried out.
\end{abstract}

Keywords: internal rate return; net present value; radio business.

\section{Introduction}

Uncertainty in business is a necessity for entrepreneurs, how entrepreneurs can face obstacles in managing business dynamics. Every century there are several economic, social, political, and even health obstacles that plague the whole world is almost sure that health problems, namely the COVID-19 pandemic from 2020 to 2021, have made entrepreneurs rethinking, or even switch directions at least to survive during the pandemic. There are no exceptions to the radio media business. Mass media indeed broadcast radio institutional has two different sides: one commercial and profit-oriented as a company/business, and two social and idealism as an editorial side. The broadcasting community sees this phenomenon diametrically by looking at the significant differences between market/commercial-oriented private broadcasters and public broadcasters serving the public. The radio media business indeed in west java most are family businesses, some studies have also demonstrated a negative relationship between family involvement and financial performance. It could be happening because of the multidimensional problem, the research, we limit it to those related to finance. This phenomenon proves that the disruption and pandemic have changed the economic climate and the calculation of profits in various business sectors, including the service, trade, and manufacturing sectors. in 2020 it is almost certain that there will be changes in the calculation of financial targets, namely the capital budget, both in terms of net present value analysis and internal rate return analysis and in 2021 where profits will be under great pressure. The service industry sector is one sector that is under heavy pressure, particularly the radio mass media business. investors, tend not to have 
a goal of how to assess the performance of companies that use public space through financial analysis. Investors tend to rely on intuition in deciding to sell, continue or even buy companies for business expansion and end up trapped in irrational behavior that leads to speculative actions. To help interpret business data, financial statements can be presented in a comparative form. According to Syahrul, S.E. (2000:180) comparative financial statements are financial statements that are presented side by side for two years or more. In a comparative financial statement, the figures contained in the financial statements for several years appear side by side in a vertical column. This format will certainly assist investors in identifying and evaluating significant companies and ratios. Financial evaluation that is often used and known by the public is the analysis of net present value and internal rate return. Assessing the company's performance can be done by comparing the current value of money and interest on deposits as a benchmark for zero risks. This is certainly very useful for investors in knowing the condition of companies in certain industrial groups to determine which is the best and more profitable in terms of the company's performance comparison. Past performance is often a good indicator of future performance. Currently, in Indonesia, there has been a lot of progress, such as in terms of the development of science, information technology, and telecommunications technology. Even though Indonesia is one of the slowest countries in the telecommunications sector, now we can see and feel the convenience provided by companies engaged in telecommunications. Business fields that were previously owned by the public were postal, telecommunications, and broadcasting. The broadcasting business, in this case, radio is one of the businesses that has been hit hard, almost seventeen months from the COVID-19 pandemic, so this research needs to be done so that all stakeholders get an idea of how the radio business is now and in the future. The main data source is obtained from broadcasters in the form of financial projections so that later this research can be useful for an overview of the radio business in West Java and how business people respond to the COVID-19 pandemic variable.

\section{Literature Review}

As far as the author knows, no similar research has been found, namely financial budgeting analysts at radio media companies in West Java, considering these companies are still closed companies and are thick with family companies, so data in the form of financial statements will be very difficult to find, therefore data which will later be processed is the primary data in the form of financial projections, which were originally from 2020 to 2025. As in the purpose of this research as a quantitative description and how entrepreneurs can survive and even stop broadcasting, it is hoped that further research can be carried out so that in the future it can be useful for all stakeholders. Currently, there are approximately 267 radio stations in West Java that have a license or better known as a broadcasting operation permit (IPP), divided into several categories, namely $215 \mathrm{FM}$ private broadcasters, 14 AM private broadcasters, and community broadcasters. as many as 30 radios, local public broadcasting institutions as many as 8 radios. the number above is indeed not small, but the radio broadcasting institution still has good business opportunities from obtaining national or regional and local advertisements. The economic potential of local media in the West Java broadcasting industry is very good, but concentrated media ownership has an impact on unfair competition, especially the unfair treatment of local private radio. local radio stations in the regions generally do not have access to capital and have limited access to the "advertising cake" of large multinational corporations controlled by certain groups. this is one of the many obstacles faced by radio in cities and/or districts in West Java which was recently hit by the COVID-19 pandemic. The data collected is primary data, i.e. data obtained directly from the source, namely each broadcasting institution which incidentally is a legal entity, this data is a financial projection or pro forma from 2020 to 2025, while the Pro forma report itself is a comprehensive financial projection report. formal to reflect planned transactions within a certain period. The pro forma report is an important component of a business plan because it can predict the profitability and financial condition of a company in the future. The pro forma report becomes an integral part to convince potential creditors and investors to provide the financial assistance needed by a company. The pro forma report also helps the owner of the company to plan how to increase the financial strength and healthy growth of the company because this report can estimate the company's financial condition for a certain period. For financial data, of course, the data scale is a ratio, so that later it can provide a clear picture and consideration in making business decisions in the radio broadcasting sector. The radio broadcasting media business in West Java experienced its golden age in the seventies until the two thousand, after the two thousand, the competition was very, very tight, starting in the nineties, they had to compete with television for advertisements, from two thousand to ten thousand. two thousand and fifteen, although it is still experiencing its golden age, at this time advertising cakes, have started to compete with advertisements 
spent on social media, so that in this era the competition is very, very tight, but when entering the year two thousand and fifteen the dynamic dynamics of business actors radio media in West Java began to be felt. In other words, after the year two thousand and fifteen advertising revenue was felt by some radio media quite heavy, plus radio media business actors are family businesses so that currently it can be said that radio broadcasting media is experiencing business turbulence, so the authors hope this research can be used as a reference. and guidelines for literacy regarding the description of the radio business in Indonesia, West Java.

\section{Research Method}

This research was carried out in December two thousand and twenty, with the hope of obtaining primary data from radio broadcast media business actors, namely financial report data, at least profit, and loss statements, we limit the population of radio broadcast media companies in West Java to members of the broadcast radio union. In the Indonesian National Board in the West Province, the number of members is one hundred and nine radios, so with a minimum sample of eighty-six broadcast media companies, however, the data is recorded, served, and then analyzed for about thirty-six broadcast radio media only. We got this data from the results of communication and correspondence from December two thousand and twenty to September two thousand and twenty-one, although the financial statements are in the form of profit and loss, there are still many shortcomings, although there are many shortcomings, hopefully, the results of this research can be reference material. In addition to profit and loss projection financial report data, direct interviews were also conducted with decision-makers regarding their financial statements and how to run the radio broadcasting media business during the two thousand twenty to two thousand twentytwo years. The population is a generalization area consisting of objects/subjects that have quality and certain characteristics determined by the researcher to be studied and then drawn conclusions. (Sugiyono, 2007: 90), So the population is not only people but also objects and other natural objects. The population isn't it either only the number of objects/subjects studied, but includes all the characteristics/properties possessed by the subject or object. Sample understanding and sampling techniques. The sample is part of the number and characteristics that owned by the population. While sampling is a process of selecting some of the population elements which is statistically sufficient so that by studying the sample and understanding characteristics (characteristics) will be known information about the state of the population. The sampling technique is a way to determine the number of samples and the selection of prospective sample members, so that each sample selected in the study can represent the population (representative) either from aspects of the quantity as well as from the aspect of the characteristics owned by the population. Sampling technique If all members of the population are selected to be members sample, then this process is called a census (saturated sample). Sampling techniques can be grouped into two, namely: 1) Probability sampling, including: simple random (simple random), proportional stratified random random), disproportionately stratified random stratified random), and cluster/sampling area; 2) Non-probability sampling, including sampling systematic, quota sampling, incidental sampling, purposive sampling, saturated sampling, and snowball sampling. Probability sampling techniques. A technique that gives equal opportunities to every member population to be selected as a sample) 1) Simple random sampling (homogeneous population) Sampling is done randomly regardless of the existing strata. The technique is only used if the population is homogeneous. 2) Proportional stratified random sampling (population is not homogeneous) Sampling is done randomly by taking into account the existing strata. This means that each stratum is represented according to its proportions. 3) Disproportionate stratified random sampling this technique is used to determine the number of samples with a stratified population but less proportional, meaning that there are several strata groups that are very small in size 4) Cluster sampling (Regional Sampling) This technique is used to determine the number of samples if the data source is very wide. Sampling is based on a predetermined population area. For example, from 27 provinces 10 provinces were taken randomly. Nonprobability sampling (Techniques that do not provide equal opportunities for everyone members of the population to be selected as samples) 1) Systematic sampling sampling is carried out based on the order of members of the population who have numbered 2) Quota sampling is carried out on members of the population who have characteristics up to a certain amount (the desired quota), 3) Incidental sampling chance-based sampling, i.e. anyone who happens to be meeting with the researcher can be used as a sample if the person who happens to be found is considered suitable as a data source. 4) Purposive sampling determination of samples based on certain considerations. 5) Saturated sampling sampling when all members of the population are used as samples. 6) Snowball sampling the determination of the sample which is initially small in number, then the sample is ordered to choose their friends to be sampled. And so 
on, so that the number of samples is increasing. Like a snowball. Referring to some of the things above, the author initially conducted a minimum sample using the Slovin formula, the population, namely members of the Indonesian National Private Broadcasting Radio Association in the West Java Region, was one hundred and nine radios, so with the Slovin formula the minimum sample was eighty-sixed samples, but in the process, there are difficulties, from December two thousand and twenty to September two thousand and twenty-one, only thirty-six data were obtained as sample data for the income statement financial statements, so that the basis for choosing the sampling method was not likely, namely Techniques that do not give equal opportunities to everyone members of the population to be selected as samples, and what the authors choose is to be purposive sampling considering the long process and data are difficult to obtain. In addition to the profit and loss financial statement data, the authors conducted interviews with decision-makers related to financial dynamics and the wheels of the radio broadcasting media business.

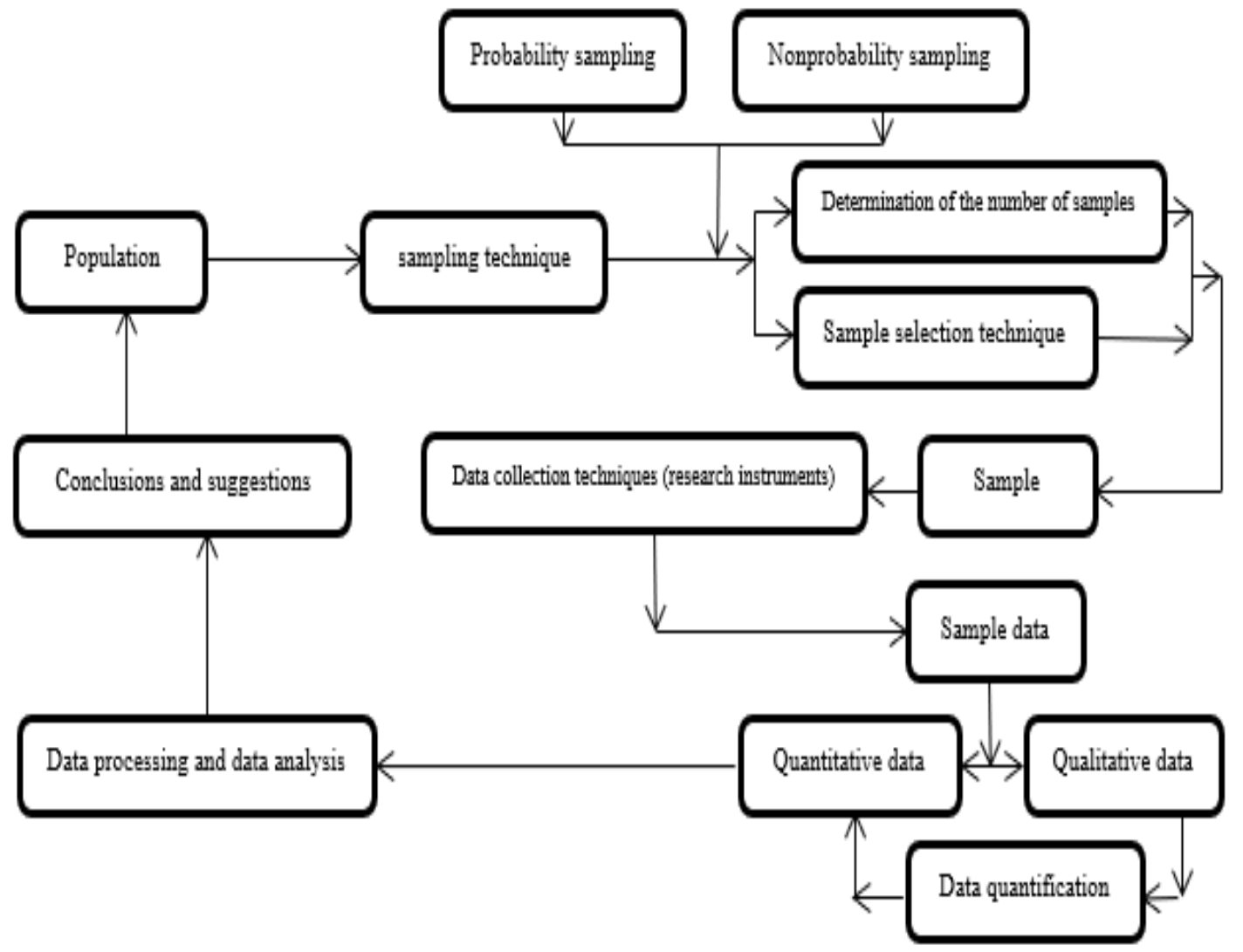

Figure 1. Sampling framework.

(Source: Sugiyono, 2017)

After the data is obtained then sorting and selecting is done and then standardization of profit and loss financial statements is made for service companies, in this case, is a radio broadcasting media services with their accounts then the formula is income, minus expenses equal to net profit or loss. However, the data obtained was not as expected, as shown. 
Tabel 1. Revenues

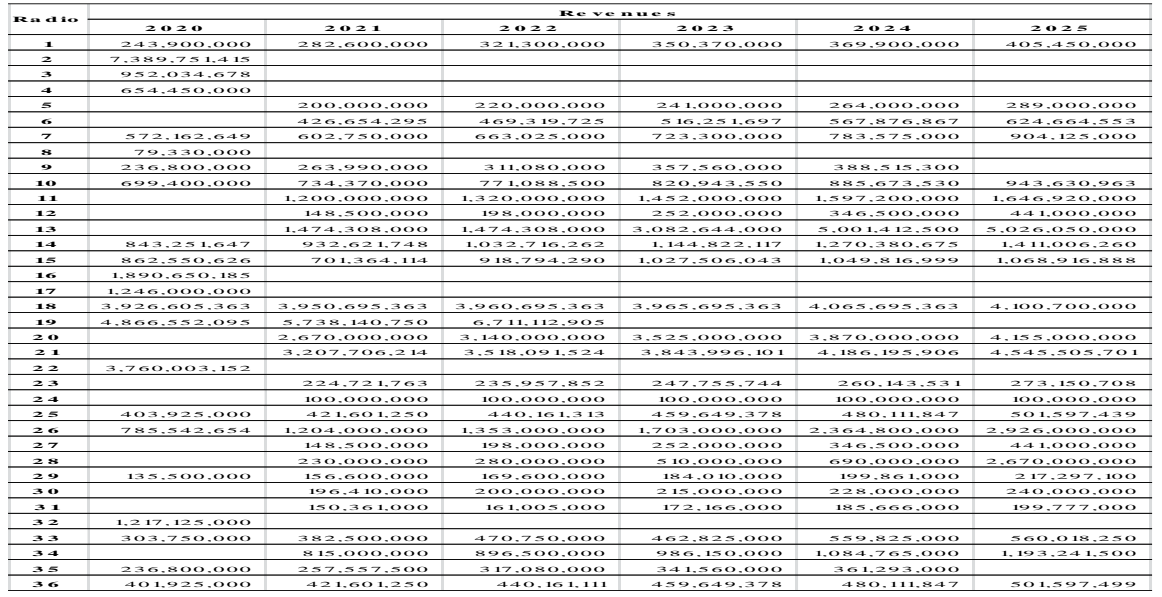

Sources: primary data, processed with excel 2010

Tabel 2. Expenses

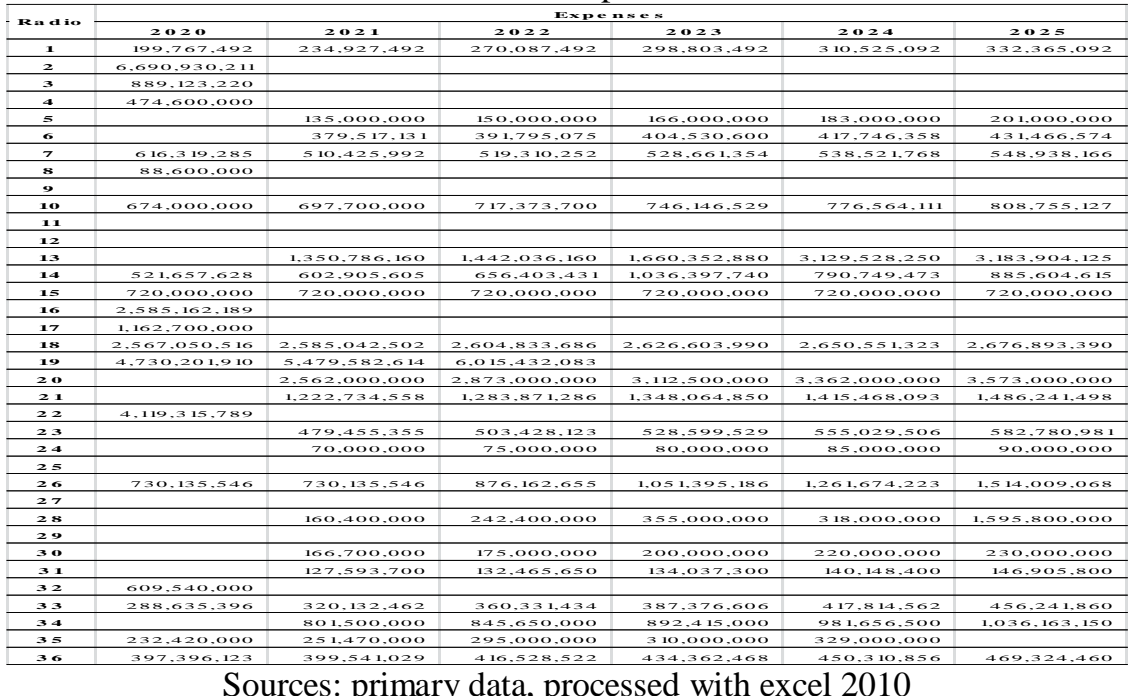

Sources: primary data, processed with excel 2010

The data above will make it easier to make an image, as an illustration of financial projections both in terms of income accounts, expenses, and net income or a net loss. After that, the author will analyze the financial budget, namely the time value of money in the form of net present value and internal rate returns, the authors hope that the results of this study will clearly show how the business conditions of radio broadcasting media in West Java are. Now we move on to the basic theory of what is projected financial statements (in this case profit and loss), then what is net present value and what is internal rate return. A Pro forma report is a formal financial projection report to reflect planned transactions within a certain period. The pro forma report is an important component of a business plan because it can predict the profitability and financial condition of a company in the future. The pro forma report becomes an integral part to convince potential creditors and investors to provide the financial assistance needed by a company. The pro forma report also helps the owner of the company to plan how to increase the financial strength and healthy growth of the company because this report can estimate the company's financial condition for a certain period. How to Make a Pro forma Report Here's how to compose a pro forma report: Calculate your company's projected earnings using realistic market assumptions. Research and discuss with experts and accountants to determine the normal annual income stream, cash flow, and asset accumulation assumptions. Estimate your total liabilities and costs. Pay attention to any existing expenses and make sure the estimates made remain realistic. Estimate the company's cash flow. This point concerns net income in the future, asset sales, dividends, stock issuance, and so on. Net present value (NPV) is the difference between the present value of cash inflows and the present value of cash outflows over some time. By 
contrast, the internal rate of return (IRR) is a calculation used to estimate the profitability of potential investments. Both of these measurements are primarily used in capital budgeting, the process by which companies determine whether a new investment or expansion opportunity is worthwhile. Given an investment opportunity, a firm needs to decide whether undertaking the investment will generate net economic profits or losses for the company. To do this, the firm estimates the future cash flows of the project and discounts them into present value amounts using a discount rate that represents the project's cost of capital and its risk. Next, all of the investment's future positive cash flows are reduced to one present value number. Subtracting this number from the initial cash outlay required for the investment provides the net present value of the investment. but from a business perspective, the firm should also know what rate of return will be generated by this investment. To do this, the firm would simply recalculate the NPV equation, this time setting the NPV factor to zero, and solve for the now unknown discount rate. The rate that is produced by the solution is the project's internal rate of return (IRR).

NPV formula.

$$
N P V=\sum_{n=0}^{r} \frac{C_{n}}{(1+r)^{n}}
$$

IRR formula

$$
0=N P V=\sum_{t=1}^{T} \frac{C_{t}}{(1+I R R)^{t}}-C_{0}
$$

\section{Results and Discussion}

The author can describe how the pro forma of the thirty-six radios in West Java is as shown in the pictures below, namely revenues, expenses, and net income or a net loss.

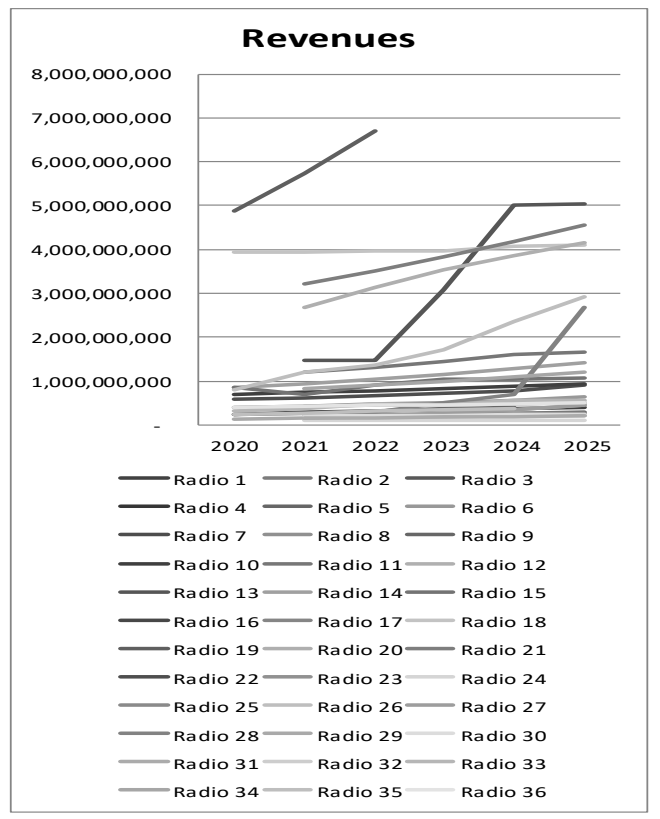

Figure 2. Revenues

(Sources: primary data, processed with excel 2010)

The table above shows that in one year on average, radio broadcasters project income below one billion rupiahs, only a few radio broadcasters project revenues above one billion rupiahs. In line with income, of course, expenses will also increase, assuming the increase in income will increase the expenses. as shown in figure 3 below. 


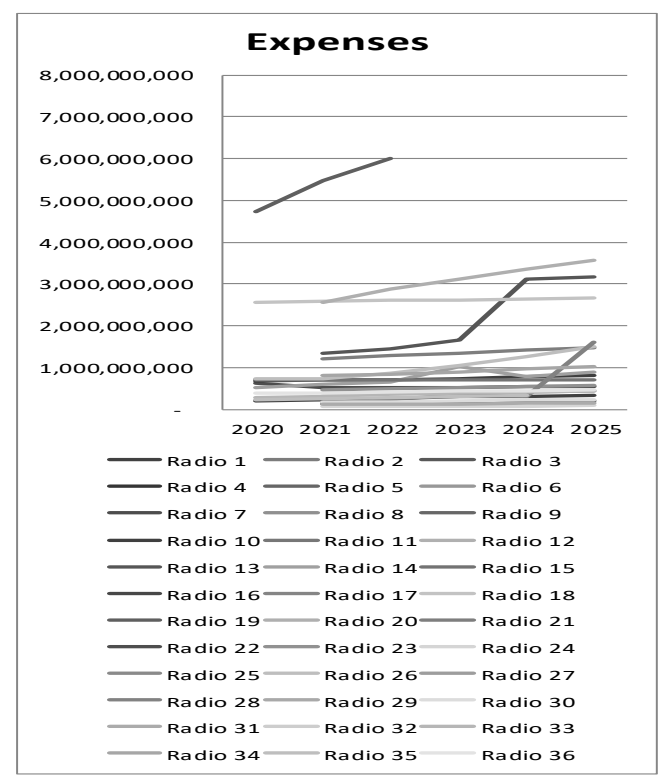

Figure 3. Expenses

(Sources: primary data, processed with excel 2010)

Contrary to the net income, it can be seen in figure 4, that the average radio broadcasting institution in West Java projects a net income of under five hundred million rupiahs, and some even project an income below zero rupiahs.

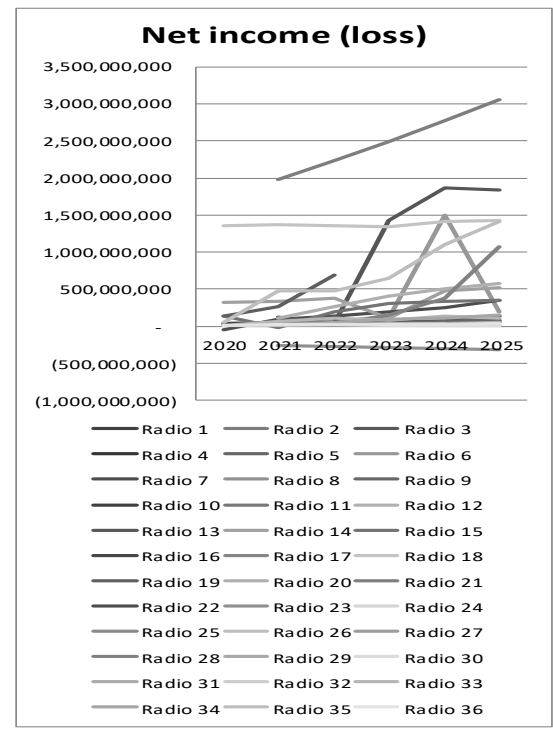

Figure 4. Net income (loss)

(Sources: primary data, processed with excel 2010)

All data show the same thing, regarding income which has fallen by about fifty percent to seventy percent, meaning that some of these radio stations are still trying to survive, but some appear to be no longer broadcasting, with an illustration that their net income is below zero rupiahs. From the initial data that the author has sorted and then selected, analyzed, and then processed to be presented in the tables above, a tentative conclusion can be drawn that it will have an unfavorable impact on the net present value and internal rate return on the average company, namely radio broadcasting institutions. 
Tabel 3. NPV and IRR.

\begin{tabular}{|c|c|c|c|c|c|c|c|c|c|}
\hline wacc & & & Net incer & (loss) & & & & & \\
\hline $20 \%$ & 2020 & 2021 & 2022 & 2023 & 2024 & 2025 & & & \\
\hline$\circ$ & 1 & 2 & 3 & 4 & 5 & 6 & & NPV & IRR \\
\hline (500.000.000) & 44.132.508 & 47.672 .508 & 51.212 .508 & 51.566.508 & 59.374 .908 & 73.084.908 & $R_{P}$ & 272.728 .829 & $-10,23 \%$ \\
\hline (500.000.000) & 698.821 .205 & & & & & & $R_{p}$ & 68.625 .837 & $39,76 \%$ \\
\hline (500.000.000) & 62.911.458 & & & & & & $-\mathrm{RP}_{\mathrm{P}}$ & 372.978 .154 & $-87,422 \%$ \\
\hline (500.000.000) & 179.850 .000 & & & & & & $-R_{p}$ & 291.770 .833 & $-64,0396$ \\
\hline (500.000.000) & & 65.000 .000 & 70.000 .000 & 75.000.000 & 81.000.000 & 88.000.000 & $R_{P}$ & 232.826 .432 & $-8,21 \%$ \\
\hline (500.000.000) & & 47.137 .164 & 77.524 .650 & 111.721.097 & 1.501.305.090 & 193.197.979 & $R_{P}$ & 382.851 .578 & $43.03 \%$ \\
\hline (500.000.000) & (44.156.636) & 92.324.008 & 143.714 .748 & 194.638 .646 & $\begin{array}{l}245.053 .232 \\
\end{array}$ & 355.186 .834 & $-R_{P}$ & 65.181 .006 & $15,62 \%$ \\
\hline (500.000.000) & $(9.270 .000)$ & & & & & & $-R_{p}$ & 423.104 .167 & \#NUM! \\
\hline (500.000.000) & & & & & & & $-R_{p}$ & 416.666 .667 & "INUM! \\
\hline (500.000.000) & 25.400 .000 & 36.670 .000 & 53.714 .800 & 74.797.021 & 109.109 .419 & 134.875 .836 & $R_{P}$ & 247.661 .446 & $-3,11 \%$ \\
\hline (500.000.000) & & & & & & & $-R_{P}$ & 416.666 .667 & \\
\hline (500.000.000) & & & & & & & $-\mathrm{RP}_{\mathrm{P}}$ & 416.666 .667 & \#NUM! \\
\hline (500.000.000) & & 123.521 .840 & 32.271 .840 & 1.422 .291 .120 & 1.871.884.250 & 1.842 .145 .875 & $R_{P}$ & 1.742 .891 .728 & $89,92 \%$ \\
\hline (500.000.000) & 321.594.019 & 329.716 .143 & 376.312.831 & 108.424.377 & 479.631.202 & 525.401 .645 & $R_{P}$ & 529.779 .292 & $62,06 \%$ \\
\hline (500.000.000) & 142.550 .626 & $(18.635 .886)$ & 198.794 .290 & 307.506 .043 & 329.816.999 & 348.916 .888 & $R_{p}$ & 98.822 .455 & $26,93 \%$ \\
\hline (500.000.000) & (694.512.004) & & & & & & $-R_{P}$ & 898.966.669 & \#NUM! \\
\hline (500.000.000) & 83.300 .000 & & & & & & $-R_{p}$ & 358.819.444 & $-83,3496$ \\
\hline (500..000.000) & 1.359 .554 .847 & 1.365 .652 .861 & 1.355.861.677 & 1.339.091.373 & 1.415.144.040 & 1.423 .806 .610 & $R_{P}$ & 3.381 .083 .450 & $272,01 \%$ \\
\hline (500.000.000) & 136.350 .185 & 258.558 .136 & \begin{tabular}{|l|l|}
695.680 .8222 \\
\end{tabular} & & & & $R_{p}$ & $\begin{array}{l}163.143 .736 \\
\end{array}$ & $37.92 \%$ \\
\hline (500.000.000) & & 108.000 .000 & 267.000 .000 & 412.500 .000 & 508.000.000 & 582.000.000 & $R_{P}$ & 410.841 .049 & 48,9896 \\
\hline (500.000.000) & & 1.984 .970 .656 & 2.234.220.238 & 2.495 .931 .251 & 2.770 .727 .813 & 3.059 .264 .203 & $R_{P}$ & 5.5966 .442 .012 & $409,13 \%$ \\
\hline (500.000.000) & (198.713.509) & & & & & & $-R_{p}$ & 554.662 .159 & "INUM! \\
\hline (500.000.000) & & (254.733.592) & $\begin{array}{l}(267.470 .271) \\
\end{array}$ & $(280.843 .785)$ & \begin{tabular}{|c|c|}
$(294.885 .975)$ \\
\end{tabular} & (309.630.273 & $R_{P}$ & 1.105.991.425 & "INUM! \\
\hline (500.000.000) & & 30.000 .000 & 25.000 .000 & 20.000 .000 & \begin{tabular}{|l|l}
15.000 .000 \\
\end{tabular} & 10.000 .000 & $=R_{P}$ & 362.343 .536 & $\begin{array}{l}-41,56 \% \\
\end{array}$ \\
\hline (500.000.000) & & & & & & & $-R_{p}$ & 416.666 .667 & HNUM: \\
\hline (500.000.000) & 55.407.108 & 473.864.454 & 476.837 .345 & 651.604 .814 & 1.103 .125 .777 & 1.411 .990 .932 & $R_{p}$ & $\begin{array}{l}1.151 .354 .594 \\
\end{array}$ & $70,79 \%$ \\
\hline (500.000.000) & & & & & & & $-R_{P}$ & 416.666 .667 & \#NUM! \\
\hline (500.000.000) & & 69.600 .000 & 37.600 .000 & 155.000 .000 & 372.000.000 & 1.074 .200 .000 & $R_{P}$ & 237.421 .018 & $34,09 \%$ \\
\hline (500.000.000) & & & & & & & - & 416.666 .667 & HNUM! \\
\hline (500.000..000) & & 29.710 .000 & 25.000 .000 & 15.000 .000 & 8.000 .000 & 10.000 .000 & $R_{P}$ & 367.769 .333 & $-44,60 \% 6$ \\
\hline (500.000.0000) & & 22.767 .300 & 28.539 .350 & 38.128.700 & 45.517 .600 & $\begin{array}{r}52.871 .200 \\
\end{array}$ & $R_{P}$ & 329.953 .570 & 2 \\
\hline (500.000.000) & 607.585 .000 & & & & & & $R_{P}$ & 5.267 .361 & 21,3 \\
\hline (500.000.000) & 15.114.604 & 67.538 & 418.566 & 448.394 & $\begin{array}{r}142.010 .438 \\
\end{array}$ & 103.776 .390 & $\mathrm{Rp}_{\mathrm{p}}$ & 209.986 .283 & 0,4496 \\
\hline (500.000.000) & & & $\begin{array}{l}50.850 .000 \\
\end{array}$ & & 103.108 .500 & $\begin{array}{r}157.078 .350 \\
\end{array}$ & & 238.618 .375 & $-4,54 \%$ \\
\hline (500.000.0000) & 4.380 .000 & 6.087 .500 & 22.080 .000 & 31.560 .000 & 32.293 .000 & & $-\mathrm{RP}_{\mathrm{P}}$ & 375.955.877 & $-33,34 \%$ \\
\hline
\end{tabular}

Sources: primary data, processed with excel 2010

The profit and loss projection financial report data above, assisted by an excel application to facilitate the calculation of the net present value and internal rate return, shows that the result of calculating the average net present value is the direction of the red down arrow, of course with consideration of the weight average cost of capital of twenty percent, with rational considerations based on government regulation number eleven years two thousand twenty-one, radio is a high-risk business, so the author gives a WACC of twenty percent, so from a business perspective, of course, it takes careful consideration to choose this business. As for the internal rate return, the author considers the assumptions from the results of interviews with several radio broadcasting institutions, a figure of five hundred million rupiahs is chosen, we get from the average interview results and consider the average number in the city or district, of course, this figure will be considered very small for those who would give up the radio business, and the result was that only a few radios exceeded the twenty percent mark. Of course, this is a calculation on paper for consideration, but from a business perspective, of course, there are still several variables to be considered. It can be seen in figure 5 and figure 6 below clearly regarding the results of the calculation of the net present value and internal rate return.

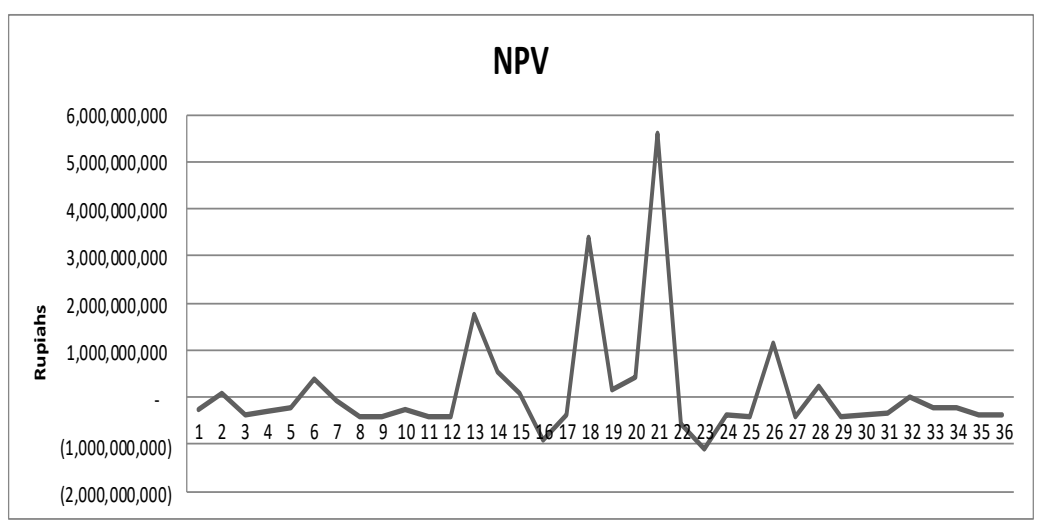

Figure 5. Net Present Value

(Sources: primary data, processed with excel 2010) 


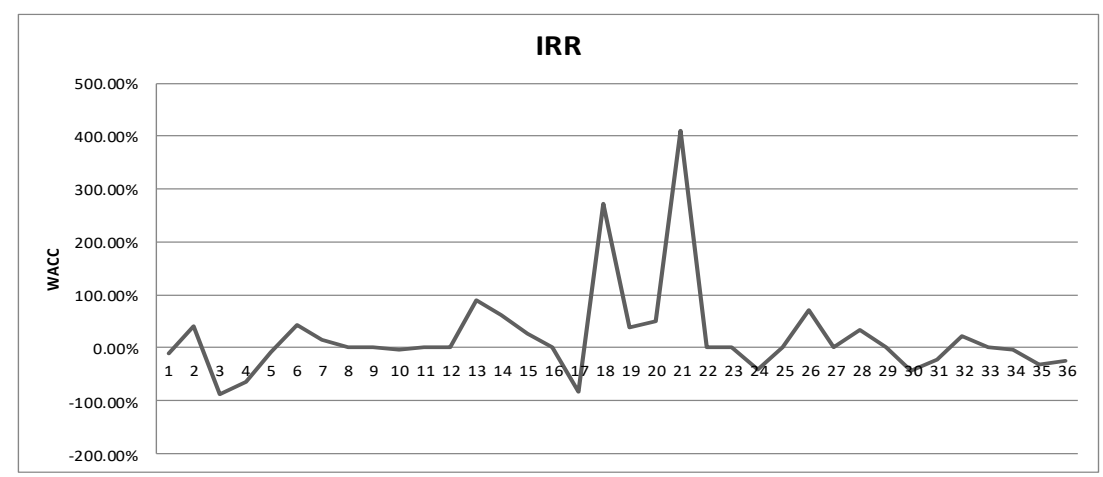

Figure 6. Internal Rate Return.

(Sources: primary data, processed with excel 2010)

\section{Conclusion and Implications}

The growth of radio broadcasting institutions in West Java has been lively since the nineteen hundred and seventies and has become a more promising radio media industry since about one thousand nine hundred and ninety-eight, or the post-reform era. In the course of business radio broadcasters, all things have positive and negative impacts, both on media producers, advertisers, especially for advertising on radio and on society as media consumers. The media industry supports the formation of media conglomerates or the concentration of media ownership. The media industry is controlled by private broadcasters who full of business interests or political interests, or the interests of both changed from "state regulation" to "market". regulation". The media industry is not based on state intervention but is shaped primarily by market mechanisms and determined by market forces. The power of radio is in proximity, proximity to listeners, locality, and form the "theater of the mind" in the mind listeners, while the advantage of television is in the audiovisuals that represent reality. Currently, there are 259 licensed West Java radios. And broadcast radio has a listener rating that is still high after television. The economic potential of local media in West Java the broadcasting industry is very great, but concentrated media ownership has an impact on unfair competition, especially the unfair treatment of local private radio. local radio stations in the regions generally do not have access to capital and have limited access to the "advertising cake" of large multinational corporations controlled by certain groups. The results of this research in what efforts should be done by local radio to maintain their business how to shape business diversification to face international competition media industry in responding to broadcasting regulations. This article aims to find a clear picture and information about local radio to face competition and challenges among the media industries through diversifying their businesses. By method The approach used in this study is a qualitative description approach, and through interviews with radio owners, and/or private radio managers. Media industry has become great economic potential, but not yet given opportunities to access capital, marketing networks, and improve the quality of broadcasts by both the government and association. Amid the pressure of the media conglomerate which makes business competition unhealthy, so the choice is to be able to survive by making efforts to diversify the non-broadcasting business. target market niche in a business that has not reachable by the large broadcasting industry that sells a wide variety the right product because in according to the habits and needs of listeners, so that they can obtain significant benefits. For that, it is necessary to review the rules regarding ownership restrictions, types of broadcasting business, and can be implemented consistently, so that radio has a reasonable business opportunity.

\section{References}

Agnes Sawir, 2005, Analisis Kinerja Keuangan dan Perencanaan Keuangan Perusahaan, Cetakan Kelima, Jakarta, Gramedia Utama.

Dajan, Anto, 1986, Pengantar Metode Statistik, jilid 1, Cetakan kesebelas, Jakarta, LP3ES.

Dajan, Anto, 1978, Pengantar Metode Statistik, jilid 1, Cetakan ketiga, Jakarta, LP3ES.

Dwi Prastowo dan Rifka Juliaty, 2005, Analisis Laporan Keuangan, Cetakan Pertama, Yogyakarta, YKPN. Fess, Niswonger, 1982, Accounting Principles, First published, South-Western Publishing Co.

Hansen, Don R Mowen dan Maryanne M, 2001, Manajemen Biaya, Edisi Kedua, Jakarta, Salemba Empat. Harrington, Diana, 1991, Corporate Financial Analysis, $4^{\text {th }}$ ed, Illinois Kentucky Publishing Co. IAI, 2004, "Standar Akuntansi Keuangan", Jakarta, Salemba Empat. 
Jusup, Al Haryono, Dasar-dasar Akuntansi, jilid 1, edisi 4, Yogyakarta, YKPN.

Jumingan, 2006, “Analisis Laporan Keuangan”, Cetakan Pertama, Jakarta:Bumi Aksara

Moh. Nazir, Ph.D, 1988, Metode Penelitian, Cetakan ke tiga, Jakarta, Ghalia.

Sudjana, DR. M.A.,M.Sc. 1975, Statistika untuk ekonomi dan niaga, jilid 1,edisi baru, Bandung, Tarsito.

Sudjana, DR. M.A.,M.Sc. 1975, Statistika untuk ekonomi dan niaga, jilid 2,edisi baru, Bandung, Tarsito.

Sudjana, DR. M.A.,M.Sc. 1975, Metoda statistika, edisi ke-4, Bandung, Tarsito.

Supranto, J, M.A, 1986, Statistik teori dan aplikasi, jilid 1, edisi keempat, Jakarta, Erlangga.

Syahrul, Muhammad Afdi Nizar, Ardiyos. Kamus lengkap ekonomi, istilah-istilah akuntansi, keuangan dan investasi.

Soehardi Sigit, Prof Dr, 2001, Metodologi Penelitian Sosial-Bisnis-Manajemen, Cetakan Kedua, Yogyakarta, Pena Persada Offset.

Sofyan Syafri Harahap, 2003, Analisis Kritis Atas Laporan Keuangan, Edisi 1-5, Jakarta, Raja Grafindo Persada.

Sugiyono, Prof Dr, 2004, Metode Penelitian Bisnis, Cetakan Keenam, Bandung, Alfabeta.

Tim Pustaka phoenix, 2007, Kamus Besar Bahasa Indonesia, Jakarta, Balai Pustaka.

Tim Redaksi Kamus Besar Bahasa Indonesia, 2002, Kamus Besar Bahasa Indonesia, Jakarta, Balai Pustaka.

Warren Carl S, James M. Reeve and Philip E. Fess, 2001, Accounting, Twentieth Edition, SouthWestern, Thomson Learning.

Eugene, F.B., Ehrhardt, M.C. (2005). Financial Management, Theory and Practice (11th international edition). South-Western. 